\title{
Retrospective comparison of tubeless and standard percutaneous nephrolithotomy
}

\section{Tüipsüz ve standart perküitan nefrolitotominin retrospektif olarak karşılaştırılması}

\author{
Esat Korğalı, Hüseyin Saygın, İsmaill Emre Ergin*, Emre Kuraç
}

Sivas Cumhuriyet University, Faculty of Medicine, Department of Urology, Sivas, Turkey

Corresponding author: İsmail Emre Ergin, MD, Sivas Cumhuriyet University, Faculty of Medicine, Department of Urology, Sivas, Turkey

E-mail: emreergin55@hotmail.com

Received/Accepted: February 02, 2020 / June 20, 2020

Conflict of interest: There is not a conflict of interest.

\section{SUMMARY}

Objective: Comparison of tubeless percutaneous nephrolithotomy (tPCNL) and standard percutaneous nephrolithotomy (sPCNL) performed in renal stone surgeries in terms of patient comfort, post-operative hospitalization time and complications.

Method: In our clinic, sPCNL was performed by placing a nephrostomy catheter in 87 patients out of 133 patients, and tPCNL was performed by placing a Double $\mathrm{J}$ catheter in 46 patients.

Results: There was no statistical difference between the two patient groups in data such as age, gender, stone size, guy's score, stone variable, and side $(p>0.05)$. Also in the perioperative data; operation time, stone-free rates, perioperative hemoglobin decrease, blood transfusion, and statistical difference between the two groups were not found ( $p>0.05)$. There was no significant difference between stone groups such as stonelessness rate, postop hemoglobin decrease, operation time and stone properties such as stone size, guy's score, stone variable $(\mathrm{p}>0.05)$. Analgesia dose, length of hospitalization, return to activity $(\mathrm{p}=0.001)$, fever during post-op period $(\mathrm{p}=0.016)$, urine leakage from the nephrostomy tract $(\mathrm{p}=0.002)$ were found to be statistically significant lower in the tPCNL group. More tPCNL was performed on the upper pole stones which was found statistically significant $(\mathrm{p}=0.008)$.

Conclusions: Tubeless PCNL operation is an end urological method that can be applied effectively and safely by experienced surgeons with advantages such as less pain in early postoperative period, shorter hospitalization, returning to physical activity earlier, less fever and less urine leakage than nephrostomy tract.

Keywords: Nephrolithotomy percutaneous, kidney calculi, urologic surgical procedures

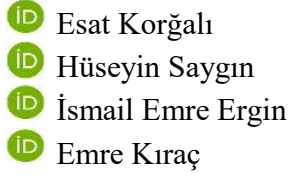

ORCID IDs of the authors: E.K. 0000-0003-0318-0353 H.S. 0000-0002-6875-0882 İ.E.E. 0000-0002-3115-0533 E.K. 0000-0002-4466-1615

Amaç: Renal taș cerrahilerinde yapılan tüpsüz perkütan nefrolitotomi (tPCNL) ve tüplü perkütan nefrolitotominin (sPCNL) etkinliği, hasta konforu, post operatif yatış süresi ve komplikasyonlar açısından kıyaslanması.

Yöntem: Kliniğimizde PCNL yapılan 133 hastadan 87 hastaya standart olarak nefrostomi kateteri yerleştirilerek yapılan sPCNL ve 46 hastaya Double J kateter yerleştirilerek uygulanan tPCNL yapıldı.

Bulgular: Yaş, cinsiyet, taş boyutu, Guy taş skoru, taş değişkenliği, taraf gibi verilerde iki hasta grubu arasında istatistiksel fark yoktu $(\mathrm{p}>0,05)$. Perioperatif verilerde; operasyon süresi, taşsızlık oranları, peroperatif hemoglobin 
düşüşü, kan transfüzyonu açısından iki grup arasında istatistiksel fark bulunmadı ( $\mathrm{p}>0,05)$. Gruplar arasında taşsızlık oranı, post-op hemoglobin düşüklügü, operasyon süresi gibi ve taş boyutu, Guy taş skoru, taş değişkenliği gibi taş özelliklerde anlamlı farklılık tespit edilemedi $(\mathrm{p}>0,05)$. Analjezi dozu, yatış süresi, aktiviteye dönüş ( $\mathrm{p}=0.001)$, post-op dönemde ateş $(\mathrm{p}=0,016)$, nefrostomi traktından idrar kaçağ $(\mathrm{p}=0,002)$ tPCNL grubunda istatistiksel olarak anlamlı düşük bulundu. Üst pol taşlarına anlamlı olarak daha çok tPCNL yapıldığı $(\mathrm{p}=0,008)$ tespit edildi

Sonuç: tPCNL operasyonu, erken postoperatif dönemde daha az ağrı, daha kısa hastanede kalış süresi, erken aktiviteye dönüş, daha az ateş ve nefrostomi traktından daha az idrar kaçağı gibi avantajları ile deneyimli cerrahlar tarafından etkin ve güvenle uygulanabilecek endoürolojik bir yöntemdir.

Anahtar sözcükler: Nefrolitotomi perkütan, böbrek taşları, ürolojik cerrahi işlemler

\section{INTRODUCTION}

There have been rapidly increasing minimally invasive procedures for urinary stone endoscopic and open surgery has almost been replaced by those options. over the past decades. Percutaneous nephrolithotripsy remains the standard procedure and first line treatment for large $(>2 \mathrm{~cm})$ renal calculi. ${ }^{1}$

Insertion of nephrostomy catheter is still considered standard procedure for drainage after PCNL (sPCNL). The nephrostomy tube provides tamponade of bleeding, access for second exploration and percutaneous chemolysis as well as drainage. First Bellman et all. ${ }^{2}$ described a modified PCNL as "tubeless PCNL (tPCNL)" technique with double $\mathrm{j}$ stent instead of nephrostomy tube. Then other modification to the tPCNL is recommending usage external ureteral catheter in lieu of double $\mathrm{j}$ stend and its named "totally tubeless PCNL". 3

In this retrospective study we aimed to compared to SPCNL and tPCNL methods to appraise the role of tPCNL technic in reducing postoperative pain, morbidity of operation hospital stays and convalescence time.

\section{MATERIAL AND METHODS}

One hundred thirty-three patients who underwent PCNL operation by single surgeon (E.K.) at our center between February 2015 and September 2018 and met the inclusion criteria were enrolled in this study. The inclusion criteria of this study were normal renal function, absence of congenital abnormalities, complete clearance of calculi. Exclusion criteria were multiple tract procedure, excessive bleeding at completion, and significant peroperative complication.

Stone location, size, type, number were not considered an elimination criteria and all patients were included in the study the above criteria were met. Urinary tract infection was checked, and no patients had an indwelling double $\mathrm{j}$ stent before the PCNL procedure. Presence and degree of hydronephrosis and location of puncture (supracostal or infracostal) were not considered in the distinction criteria.

Patients in group sPCNL $(\mathrm{n}=87)$ operated standard nephrolytholitotomy with nephrostomy tube placement after stone removal, while those in other group tPCNL $(n=46)$ had antegrade placement of a double J stent across percutaneous access, without a nephrostomy tube after procedure.

All patients underwent preoperative prophylactic antibiotherapy. The procedure was performed under general anesthesia at prone position. Percutaneous puncture and tract dilatation was made with fluoroscopic guidance using biplanar Carm fluoroscopy.

Stones were taken out using a $26 \mathrm{~F}$ nephroscope through a 30F Amplatz sheath. Size of nephroscope and Amplatz sheath were similar in two the groups. Combination of ultrasonic and pneumatic lithotripter was used for disintegration of the stone. Fluoroscopy and pyelography were used to checked the stone-free status at the end of the operation and residual fragments $<4 \mathrm{~mm}$ were considered clinically insignificant fragments (CIRF).

In group sPCNL, a 20F nephrostomy tube (reentry) was placed across the PCNL tract. The nephrostomy tube was taken at 72 hours of operation and after plain radiography of the KUB or antegrade nephrostography. In group tPCNL, a 4,8- 6F/24-26 cm Double-J stent was put in via antegrade way, and the Amplatz sheat site was sutured with $2 / 0$ silk suture.

The ethics committee of the Cumhuriyet University Non-Interventional Clinical Research approved this protocol (Approval date/number: 07.11.2018/2018-11/07).

\section{RESULTS}

The both groups were similar in age and sex and in metabolic and pyleocalicial system anatomic features. The mean age of patients in group sPCNL was 48.1 (Range: 6-80) years and in group tPCNL, 
it was 50.8 (Range: 12-78) years. The male: female ratio in both groups was approximately $3: 1$. The mean stone size in group sPCNL was $835.3 \pm 304.2) \mathrm{mm}^{2}$ and in group tPCNL, $795 \pm 480.5 \mathrm{~mm}^{2}$. This features were similar in both groups $(\mathrm{p}>0.05)$. The mean stone $\mathrm{HU}$ in group sPCNL was $911.8 \pm 223,2$ and in group tPCNL 895.4 \pm 197.8 . Stone HU features in both group were comparable $(\mathrm{p}>0.05)$.
Most of the stones in group sPCNL were located in the lower calyx $(50 \%)$ and the stones in group tPCNL were mostly located in the middle calyx and renal pelvis (58.7\%). This is only significantly different parameter in this two groups $(\mathrm{p}=0.013)$. Guy's scores and stone variable scores were similar in both groups $(p>0.05)$. This features summarized in Table 1.

Table 1: Patient and stone related data

\begin{tabular}{|c|c|c|c|}
\hline & sPCNL & tPCNL & $\mathrm{p}$ \\
\hline Age & $48.1 \pm 17.6$ & $50.8 \pm 18.7$ & 0.397 \\
\hline BMI (kg/m2) & $25.0 \pm 3.5$ & $25.9 \pm 4.1$ & 0.782 \\
\hline \multicolumn{4}{|l|}{ Sex } \\
\hline Female (\%) & $30(34.5)$ & $17(36.9)$ & \multirow{2}{*}{0.479} \\
\hline Male (\%) & $57(65.5)$ & $29(63.1)$ & \\
\hline Stone size & $835.3 \pm 304.2)$ & $795 \pm 480.5)$ & 0.578 \\
\hline Stone HU & $911.8 \pm 223.2$ & $895.4 \pm 197.8$ & 0.676 \\
\hline \multicolumn{4}{|l|}{ Stone localization } \\
\hline Upper & $5(5.7)$ & $7(15.2)$ & \multirow{3}{*}{0.013} \\
\hline Medium & $38(43.6)$ & $27(58.7)$ & \\
\hline Lower & $44(50)$ & $12(26)$ & \\
\hline \multicolumn{4}{|l|}{ Guy's Score } \\
\hline 1 & 38 (43.6) & 17 (36.9) & \multirow{3}{*}{0.21} \\
\hline 2 & $37(42.5)$ & $17(36.9)$ & \\
\hline 3 & $12(13.7)$ & $12(26)$ & \\
\hline \multicolumn{4}{|l|}{ Stone Variable } \\
\hline 1 & 40 (45.9) & $15(32.6)$ & \multirow{3}{*}{0.11} \\
\hline 2 & $41(42.5)$ & $30(65.2)$ & \\
\hline 3 & $6(6.9)$ & $1(2.1)$ & \\
\hline
\end{tabular}

Mean operative time for group sPCNL was 69.09 min (Range: $30-260 \mathrm{~min}$ ) and group tPCNL 60.54 min (Range: 30-90 min) ( $>>0.05)$. Postoperative hemoglobin drop of the two groups showed no statistical significances $(p>0.05)$. The mean analgesic requirement was $122.6 \mathrm{mg}$ Tramadolol in group sPCNL and $92.9 \mathrm{mg}$ Tramadolol in group tPCNL in postoperative first 24 hours. The difference was statistically significant between two groups $(\mathrm{p}=0.01)$. Urinary extravasation rates were $26.4 \%(n=23)$ in group $\mathrm{sPCNL}$ and $4.3 \%(\mathrm{n}=2)$ in group tPCNL. The difference was statistically significant between two groups $(p=0,002)$. The mean length of hospital stay was 2.89 days for group sPCNL and 2.04 days for group tPCNL and it was statistically significant $(\mathrm{p}<0,001)$. The results and complications were displayed in Table 2. 
Table 2: Peroperative patient outcomes

\begin{tabular}{|c|c|c|c|}
\hline & sPCNL & tPCNL & $\mathrm{p}$ \\
\hline \multicolumn{4}{|c|}{ Access Localization (n (\%)) } \\
\hline Upper & $1(1.15)$ & $4(8,7)$ & \multirow{3}{*}{0.022} \\
\hline Medium & $70(80.4)$ & $39(84.7)$ & \\
\hline Lower & $16(18.3)$ & $3(6.5)$ & \\
\hline \multicolumn{4}{|c|}{ ES Replacement Need (n (\%)) } \\
\hline $\mathrm{No}$ & $77(88.5)$ & $45(97.8)$ & \multirow[t]{2}{*}{0.06} \\
\hline Yes & $10(11.4)$ & $1(2.1)$ & \\
\hline \multicolumn{4}{|l|}{ High Fever (n (\%)) } \\
\hline Yes & $28(67.8)$ & $6(13.1)$ & \multirow[t]{2}{*}{0.016} \\
\hline No & $59(32.1)$ & $40(68.9)$ & \\
\hline \multicolumn{4}{|l|}{ Urinary Extravasation } \\
\hline Yes & $23(26.5)$ & $2(4.3)$ & \multirow[t]{2}{*}{0.002} \\
\hline No & $64(73.5)$ & $44(95.5)$ & \\
\hline \multicolumn{4}{|l|}{ Stone Free Rate (n (\%)) } \\
\hline Stone Free & $74(85.1)$ & $42(91.3)$ & \multirow[t]{2}{*}{0.305} \\
\hline Residue & $13(14.9)$ & $4(8.7)$ & \\
\hline Operation Time & $69.1 \pm 30.1$ & $60.5 \pm 16.3$ & 0.112 \\
\hline Length Of Stay & $2.8 \pm 0.7$ & $2.0 \pm 0.8$ & $<0.001$ \\
\hline Analgesic Requirement & $122.6 \pm 26.1$ & $92.9 \pm 29.0$ & 0.409 \\
\hline \multicolumn{4}{|c|}{$\begin{array}{l}\text { Note } \\
\text { ES: Erythrocyte Suspension, sPCNL: Standard percutaneous nephrolithotomy, tPCNL: Tubeless percutaneous } \\
\text { nephrolithotomy }\end{array}$} \\
\hline
\end{tabular}

\section{DISCUSSION}

Improving patient comfort, shortening the length of stay in hospital and returning to early daily activity are targeted after surgery in these days. For this purpose, in 1997, Bellman et al. ${ }^{2}$ described the concept of tubeless PCNL. PCNL procedure without a nephrostomy tube with an internal ureteral double $\mathrm{j}$ catheter showed that having lesser morbidity and improved convalescence time than a standard PCNL. ${ }^{4-7}$ Initially, authors recommended that the tubeless procedure when appropriates strict inclusion criteria and they reported that use of an indwelling ureteral stent results in more discomfort from stend related symptoms in the long term. ${ }^{8}$ Next studies have shown that tubeless PCNL procedure was safe and effective even hard cases as patients with solitary kidney, multiple renal access or supracostal access tract or requiring bilateral simultaneous PCNL. ${ }^{9-11}$

We confirmed that tubeless PCNL procedure was as safe and effective as standard PCNL with this our study. Also we showed that tubeless procedure has advantage with shorter stay in hospital and convalescence time, less requirement of analgesia, lower rate of urinary extravasation to standard PCNL.
Recently, new modifications were described by the miniaturization of instruments as external ureteral catheterization and totally tubeless PCNL. ${ }^{12-14}$ These modified techniques were safe and effective and further improve patient comfort after the operation. We use this procedure in daily practice but, we did not include this group in our study due to the limited number of cases.

Several authors were claimed that the tubeless PCNL has morbidity like stend related discomfort such as urgency, frequency, painful urination, flank and bladder pain. ${ }^{12} \mathrm{We}$ observed stend related discomfort in our patients too but this is not very severe. The lack of data in this regard is one of the limitations of this study.

\section{CONCLUSION}

Our retrospective trial confirmed statistically significant superiority of tubeless procedure over standard PCNL with nephrostomy tube in terms of postoperative discomfort, pain control, morbidity, stay in hospital, and period of complete convalescence.

\section{REFERENCES}

1. Türk C, Petř́k A, Sarica K, et al. EAU Guidelines on Diagnosis and Conservative Management of Urolithiasis. Eur Urol. 
2016;69(3):468-474.

doi:10.1016/j.eururo.2015.07.040

2. Bellman GC, Davidoff R, Candela J, Gerspach J, Kurtz S, Stout L. Tubeless percutaneous renal surgery. J Urol 1997;157:1578-1582.

3. Mercado A, Fernández MI, Recabal $\mathrm{P}$, et al. Immediate postoperative morbidity in patients with indwelling double-J stent versus overnight-externalized ureteral catheter after tubeless percutaneous nephrolithotomy: a prospective, randomized study. Urolithiasis 2013;41:253-256.

4. Gonulalan U, Cicek T, Istanbulluoglu O, Kosan M, Ozturk B, Ozkardes H.. Tubeless percutaneous nephrolithotomy is effective and safe in short- and long-term urinary drainage. Urolithiasis 2013 41, 341-346.

5. Delnay KM, Wake RW. Safety and efficacy of tubeless percutaneous nephrolithotomy. World J Urol 1998; 16:375-377.

6. Feng MI, Tamaddon K, Mikhail A, Kapstein JS, Bellman GC. Prospective randomized study of various techniques of percutaneous nephrolithotomy. Urology 2001;58:345-350.

7. Agrawal MS, Agrawal M, Gupta A, Bansal S, Yadav A, Goyal J. A randomized comparison of tubeless and standard percutaneous nephrolithotomy. J Endourol. 2008;22(3):439442. doi:10.1089/end.2007.0118

8. Paul EM, Marcovich R, Lee BR, Smith AD. Choosing the ideal nephrostomy tube. BJU Int 2003;92:672-677.
9. Weld KJ, Wake RW. Simultaneous bilateral tubeless percutaneous nephrolithotomy. Urology 2000;56:1057

10. Shah HN, Kausik VB, Hegde SS, Shah JN, Bansal MB. Safety and efficacy of bilateral simultaneous tubeless percutaneous nephrolithotomy. Urology 2005;66:500-504.

11. Shah HN, Kausik VB, Hegde SS, Shah JN, Bansal MB. Tubeless percutaneous nephrolithotomy: A prospective feasibility study and review of previous reports. BJU Int 2005;96:879-883.

12. Gonen M, Ozturk B, Ozkardes H. Double-J Stenting Compared with One Night Externalized Ureteral Catheter Placement in Tubeless Percutaneous Nephrolithotomy. J Endourol 2009; 23(1): 27-32

13. Chung HS, Jung SI, Yu HS, et al. Modified totally tubeless percutaneous nephrolithotomy: Is it an effective and safe treatment option for renal and upper ureteral stones?. Wideochir Inne Tech Maloinwazyjne. 2016;11(4):240246. doi:10.5114/wiitm.2016.64447

14. Gupta S, Maurya AK, Pal DK. Observational prospective study for surgical outcome and anesthetic feasibility of tubeless and totally tubeless supine PCNL: A single centre initial experience. Turk J Urol. 2018;45(2):146-149. doi:10.5152/tud.2018.97345 